\title{
Path-dependency and policy learning in the Dutch delta: toward more resilient flood risk management in the Netherlands?
}

\author{
Arwin van Burren $^{1}$, Gerald Jan Ellen ${ }^{2}$ and $\underline{\text { Jeroen F. Warner }}^{3}$
}

\begin{abstract}
Dutch flood management policy was for a long time dominated by a protection-oriented approach. However, in the last 10 years a more risk-oriented approach has gained ground, denoted by the introduction of the concept of multilayered safety in 2009 in the National Water Plan. Since then, the dominant policy coalition focusing on resistance has found itself competing with a growing community that emphasizes the importance of resilience. In this paper we analyze the process of policy learning in Dutch flood risk management toward a more resilient paradigm, and the resulting outcomes in terms of regime change and stability. To understand the actual degree of change we unpack the mechanisms of path dependency characterizing the current flood policy regime and how they influence the impact of policy learning in terms of regime change. We conclude that specific mechanisms of path dependency, for example, the existing power asymmetries between competing coalitions and the intricate complexity of flood policies, prevent institutional change, but cannot prevent ideas about resilience slowly gaining more impact.
\end{abstract}

Key Words: flood risk management; institutional change; path dependency; policy learning; resilience

\section{INTRODUCTION: EXPLAINING GRADUAL CHANGE IN DUTCH FLOOD RISK MANAGEMENT}

The Netherlands is well known for its long history of flood defence (Mostert 2006, Verkerk and Van Buuren 2013). The Dutch government reacted upon the large flooding of 1953 with a huge program of structural measures to improve flood protection. It also introduced elaborate flood protection standards, embedded in national law and regulations. The leading approach in flood risk management well into the 1990s, then, was to focus on structural defenses to prevent the country from flooding (Vis et al. 2003). Many authors have stressed the continuity in the Dutch flood management approach, labeling it as institutional inertia (Van den Brink and Meijerink 2006), only "discursive shifts" (Wiering and Arts 2006), regime stability (Van Buuren et al. $2015 a$ ), or path dependency because of past investments in structural defence infrastructure (Hegger et al. 2016). However, after two near-flood events in 1993 and 1995 and growing political priority given to landscape values, ecology, and nature restoration, land-use planning found its way back onto the flood risk management policy agenda (Immink 2007, Pols et al. 2007, Warner et al. 2013), and resulted in the "Room for the River" program in 2000 .

Although still controversial, this latter aspect has gained momentum in Dutch water policy. The Dutch National Water Plan (Ministry of Public Transport and Water 2009) introduced multilayer safety as a flood policy framework. Multilayer safety (MLS) combines measures at the three "layers" of flood risk management: flood defence, spatial planning and disaster, and crisis management.

There are thus signs that the Dutch flood risk system, in spite of its path dependency, is gradually changing. This would seem to be the result of policy learning as the limits of the traditional approach become more and more visible (higher costs, growing implementation problems) and the potential consequences of climate change such as sea-level rise and higher river discharges are promoted up the political agenda. The current system of flood risk management shows many technical, cultural, financial, and institutional characteristics of path dependency. That not only makes policy learning highly difficult, but especially hinders making the step from learning to change or even system transformation (Pahl-Wostl et al. 2013). Path dependency seems particularly entrenched in the Dutch flood policy domain. But until now we did not know how this path dependency has impacted upon processes of learning and change. This is also a highly relevant theoretical puzzle: how to combine ideas about stability and change and how to understand the role of path dependency, a concept that is often accused of being unable to explain change, when studying policy dynamics (Kay 2005, Peters et al. 2005, Howlett and Cashore 2009).

In this paper we analyze the gradual policy shift in Dutch flood risk management toward a more resilient paradigm, and the resulting outcomes in terms of regime change and stability (Wison 2000). To understand the actual degree of change we unpack the mechanisms of path dependency characterizing the current flood policy regime and how they influence the impact of policy learning in terms of regime change.

\section{TOWARD MORE RESILIENCE IN FLOOD RISK MANAGEMENT}

Resilience is the ability to deal with the unexpected, when hazard turns into danger, and to resist its effects (Wildavsky 1985). It is to accept that a system cannot be fail-safe; it is to accept manageable risks to make a system "safe-fail." Introducing the concept of resilience in a certain policy domain will "require new forms of human behaviour with a shift in perspective from the aspiration to control change in systems, assumed to be stable, to sustain and generate desirable pathways for societal development in the face of increased frequency of abrupt change" (Folke et al. 2005:443).

There are many different definitions and interpretations of the concept of resilience (Brand and Jax 2007). For the purpose of this article, we see merit in a more constructivist approach of resilience to take into account more relational and institutional issues that play a role in building resilience, like learning and path 
dependency (Pahl-Wostl et al. 2013, Sjöstedt 2015, Stone-Jovicich 2015). In the Netherlands flood risk management sector, the concept of resilience has been studied quite extensively from an engineering perspective (Vis et al. 2003, de Bruijn 2004, Klijn et al. 2004, Mens et al. 2011). This also goes for Dutch-led studies of resilience and flood risk management outside of the Netherlands such as New York (Aerts 2014) and the German Rhine basin (Becker et al. 2015). In the Netherlands resilience thinking has only been grudgingly accepted, which is especially illustrated by a cautious paradigm shift in river management toward more space for the river (Van Buuren et al. 2015b).

This struggle is reflected today in the struggle between those favoring a multilayer approach, i.e., flood infrastructure, land-use planning, and crisis management, and those whose reasoning inevitably favors an exclusive reliance on dikes and risk assessment (Jongejan et al. 2012). Although there is growing insight in the necessity to take care of residual flood risks and to enhance societal and spatial resilience, the dominant principle of Dutch flood risk management is "prevention is better than cure" and "better safe than sorry." The institutional path dependency within this domain hinders a shift toward more resilient flood risk governance.

\section{Analyzing policy stability: elements of path dependency}

In line with the rest of Western Europe, the Netherlands appears to have made the change from flood defense to flood risk management. A persuasive and much-peddled storyline is that flood events at the turn of the Millennium showed the ineffectiveness of institutional and technological arrangements and ushered in flood risk management approaches that "make space for the river" (K. Krieger 2013, unpublished manuscript). Krieger, however, shows that for the UK and Germany this observation is far too simplistic. History plays an important part. Krieger argues that institutional variables, in particular sets of standards, procedures, and structures, can explain the differential choices made by flood managers in Germany and England and urges similar analysis for the Netherlands and France, which have other state traditions. These challenges make a lot of sense for the Netherlands; even more than in Germany, the institutional legacy in the highly exposed, densely populated Netherlands can be expected to display a strong "stickiness."

The concept of path dependency indeed seems helpful in explaining Dutch flood policy stability. The focus on path dependence developed as a response to the tendency to ignore memory, history, notably in economics, although it is just as much an antidote to delusions of social engineerability in complex systems.

Many have discussed the advantages and disadvantages of the concept in explaining why policies seem to be resistant to change and why new policies are normally more of the same (Wilsford 1994, Pierson 2000, Kay 2005, Peters et al. 2005, Howlett and Cashore 2009). Based upon Arthur's (1994) seminal work, Pierson (2000) has presented the main reasons why path dependencyinstitutionalized policy ideas, structures, and approaches - seems to be an important characteristic of public policies, which he summarizes as "increasing returns." Once a path is entered into, the costs of leaving it are too high to make it a reasonable option. Evolving systems "are sensitive to initial conditions [...] once the system 'chooses' one branch over another and travels sufficiently far along that path, it stabilises and the system settles into its new evolutionary pathway" (Reed and Harvey 1992:363-364).

Pierson (2000) argues that four characteristics of politics make path dependency particularly prevalent: the conservative nature of institutions, the high density of institutions creates barriers to entry, power asymmetries are self-reinforcing, while the complexity of policy environments gets in the way of learning. Politicians normally want to bind their successors and they are compelled to bind themselves by removing certain options "from their future menu" (Pierson 2000:262). He furthermore underlines that the absence or weakness of efficiency-enhancing mechanisms of competition (between, for example, different policy paradigms) and mechanisms for learning; the shorter time horizons of political actors; and the strong status quo bias generally built into political institutions, also contribute to the path dependency of policies and politics.

Within the domain of flood protection there is not only the path dependency of institutions and policies, but also of the measure used. Geels (2004) calls this the "hardness" of a measure, which has to do with its physical structure but also with economic aspects, e.g., sunk costs. Gerrits and Marks (2008) showed how the initial choice for flood protection by means of dikes, also starts a process of increasing returns, which makes it nearly impossible to leave that particular path: because of the sunk costs of diking and its strong interrelatedness with the geometry of landscape functions, dike-based flood protection remains much cheaper than alternative options. Past choices led to a vicious cycle of investment in ever more advanced technology, reducing the space for "softer" forms of flood management (Wesselink et al. 2015).

\section{ANALYZING POLICY CHANGE: POLICY LEARNING AND CHANGING COALITIONS IN COMPLEX SYSTEMS}

Although some authors have criticized path dependency theory (Kay 2005) for its inability to explain policy change and the pitfalls of determinism, other authors have relied on path dependence theories to analyze policy change (Peters et al. 2005). Pathdependence theories (as historical institutionalist approaches) focus upon the institutional components of policy domains. Although institutions may be rigid, there would seem to be much more room for (incremental) change at the level of ideas and discourse. Yet, the hypothesis that policy ideas are easier to change than institutions has proved debatable. Peters et al. (2005) emphasize that much stability comes from an apparent consensus about the main policy ideas underlying a dominant policy paradigm. Sabatier (1993) argues that policies persist primarily because of the persistence of the shared policy beliefs that undergird them. Actors in the policy process are reluctant to dismiss their core beliefs, although they may be willing to dispense with more peripheral beliefs in order to hold on to the core. These hegemonic ideas may in turn be undergirded by prestige and material resources, a very visible infrastructure inscribed in the Dutch landscape, and a sectoral interest in keeping it that way. But are they cast in stone or is there progressive insight?

Ingram and Fraser (2006), adopting Sabatier's (1993) concept of policy learning, distinguish between eight sources of policy change in a path-dependent institutional context. For our purposes we note that they implicitly distinguish between direct ideational changes (for example, because of positive feedback for 
change due to obvious failure of the previous policy, the role of science and the emergence of new policy images) and indirect ideational changes (due to the installation or discovery of new venues and changes in the composition of policy networks and the entrance of new actors). These two appearances of ideational change occur within the context of a policy subsystem. External system events are as important to take into account as potential source for ideational change: changes in socioeconomic conditions, in public opinion, in the systemic governing coalition, and in other subsystems can become important triggers for change (Table 1).

Table 1. Sources of policy change.

\begin{tabular}{l}
\hline \hline External system events \\
Changes in socioeconomic conditions: the need for cutbacks can \\
become a trigger to think about policy reform. \\
Changes in public opinion: support for some policy measures can \\
evaporate when the sense of urgency diminishes and other issues \\
become more important. \\
Changes in the systemic governing coalition: when new actors enter \\
the political arena, other issues can become relevant. \\
Changes in other subsystems: changes on other policy levels or in \\
other policy domains can provoke change in a policy system \\
Internal subsystem dynamics \\
Direct New insights from science \\
Existing strategies fail \\
Indirect New actors enter the policy arena \\
New venues are installed / become available \\
\hline
\end{tabular}

\section{Outcomes of learning: regime change}

To know whether policy learning results in durable altered practices and routines, it is necessary to know whether learning results in regime changes: changes within the institutional structure of a policy domain, the distribution of responsibilities and resources, the (financial) rules of the game, and the regulatory procedures (Wison 2000, Menz and Vachon 2006). Following Streeck and Thelen's (2005) typology, we can make a distinction between the process of change and the result of institutional change (Table 2).

Table 2. Process and result of institutional change (Streeck and Thelen 2005).

\begin{tabular}{cccc}
\hline \hline & \multicolumn{2}{c}{ Result of change } \\
\cline { 2 - 4 } & Incremental & $\begin{array}{c}\text { Reproduction by } \\
\text { adaptation }\end{array}$ & Discontinuity \\
\hline $\begin{array}{c}\text { Processof } \\
\text { change }\end{array}$ & Abrupt & $\begin{array}{c}\text { Survival and } \\
\text { transformation } \\
\text { return }\end{array}$ & $\begin{array}{c}\text { Breakdown and } \\
\text { replacement }\end{array}$ \\
\hline
\end{tabular}

We analyze policy learning within the Dutch flood risk domain, the resulting regime changes, and the mechanisms of path dependency that explain these outcomes. We are not so much interested in the sources of path dependency, as in how these (potential) sources actually function in impeding fundamental regime adjustments. By analyzing these sources in action, it becomes clear how path dependency in practice functions and impacts upon learning and institutional change.

\section{METHODS}

A series of policy analytical studies in the flood risk management domain during 2012-2015 formed the present article (van Buuren and Ellen 2013, Ellen and van Buuren 2014, van Buuren et al. $2015 b$ ). In these studies we interviewed over 30 directly involved actors. They were experts, civil servants, and responsible authorities at national, regional, and local levels (van Buuren and Ellen 2013, Ellen and van Buuren 2014, van Buuren et al. 2015b). Furthermore, a survey was conducted (Ellen et al. 2013). In addition, we were actively engaged in various meetings among experts, practitioners, and officials discussing the issue of multilayer safety. Over 10 interactive meetings were organized between 2012 and 2015 to discuss the concept of multilayered safety (MLS). These interactive meetings had a focus on the institutional, legal, financial, and societal feasibility of the concept of MLS. Policy makers, from a national, regional, and local level, and practitioners and scientists were involved. The earlier meetings in 2012-2014 were organized on the design of policy and institutional arrangements with the aforementioned stakeholders (Ellen and van Buuren 2014). We were in a position to organize and/or observe these meetings and the reaction of key players to proposals for introducing MLS. In addition we analyzed secondary sources compiled by other authors: existing descriptions of the Dutch flood management regime in transition (Van der Brugge 2009, Immink 2007), contributions to the debate on flood risk management reform (Van der Most 2010), and on diverse professional Internet forums. We made use of the contributions of some of our postgraduate students who carried out MSc-level thesis work on this topic (van Zuijlen 2012, Van der Horst 2013). In addition, two pilot projects in the west of the Netherlands (city of Dordrecht, and the Island of Marken close to Amsterdam) and one pilot project in the east (the Delta of the rivers Ijssel and Vecht) in which the concept of multilayered safety was applied were evaluated (Van Buuren et al. 2015b).

\section{POLICY LEARNING ON FLOOD RISK MANAGEMENT IN THE NETHERLANDS}

As stated in the introduction, the institutionalization of the Dutch flood risk management approach was strengthened in research, policy, and society in the decades after 1953. The Dutch flood risk regime has a number of characteristics that illustrate its strong institutional basis:

- A legally anchored funding scheme to keep the dike rings up to the level of the legally binding flood protection standards. This cost is pooled between the national Treasury and the regional authorities.

- Responsibilities for flood protection are allocated to dedicated organizations: the national agency of public (water) works and the regional water boards.

- The Expertise Network for Flood Protection (ENW). This institutionalized network of flood risk management experts, mostly civil engineers, has existed since 1965 . ENW gives requested and unrequested advice to the ministry of infrastructure and environment. Their advice is literally always adopted.

- Legal standards for flood risk and accompanying legal assessment (Wettelijk Toets Instrumentarium) and design guidelines for how to maintain flood defences (Leidraden) consisting of extensive guidelines and technical reports. 


\section{Developments within the flood domain}

Since the near-floods of 1993 and 1995 Dutch water management has seen a bifurcation, a choice that was never made wholeheartedly. Although the shock of the near-flood in the south and southeast led to a crash program of hard defences (kaden), it also opened up political space for greener, nonstructural alternatives. There were however discursive hurdles to be overcome to make advocates of the traditional approach of flood risk management move out of their comfort zone of structural works.

When this eventually led to the launch of the Room for the River program in 2000, the discursive limits were overstepped, however, by drawing in tentatively designating areas for so-called "calamity polders," polders to be evacuated and inundated in case of floods to save others, a clear case of intraregional risk distribution that clashed with an ingrained Dutch self-image of solidarity.

In 2001 a multilevel interauthority agreement (NBW) was signed. Based on a policy document, Water Policy for the 21st century (WB21) suggested water should be detained before it is drained to the sea, and urban space should be freed up and allocated to water bodies to absorb storm-water flood risk. Detention proposals, however, did not extend to the upstream plains in France, Belgium, or Germany. The underlying assumption of WB21 was that there would be no casualties in case of flooding.

This optimistic perspective, however, soon started to shift. Starting in 1992, a sequence of safety/risk mapping exercises (Marsroute) had been started. The goal of these exercises was to make a quantitative assessment of the actual strength of dikes, but also to take other uncertainties, other than only the height of the dikes, on board. These exercises were initially semiconfidential, as the idea that dikes can always fail, that there is always a residual risk of a flood disaster happening, and that there may be considerable uncertainty, was something of a taboo within and outside the Public Works department ${ }^{[1]}$.

In 2004 the Dutch Public Health and Environment Institute (RIVM) prepared an independent study (Ten Brinke and Bannink 2004) for the Ministry of Transport, Public Works and Water Management for the first time assessing flood safety by the same standards as other external risks, such as air crashes, industrial accidents, or terrorist attacks. This risk assessment approach forced water professionals to contemplate what would be an acceptable death toll in a certain region over a certain time frame and assess individual and group risk.

Hurricane Katrina ravaging New Orleans in August 2005 served as a wake-up call that the Netherlands was not $100 \%$ safe either. The current Minister of Public Works, then Vice-Minister, visited the area, and while the recovery works proved a boost for Dutch engineering self-confidence, the shock also spurred serious investigation of evacuation options, an area neglected in Dutch flood risk management since the catastrophic storm surge of 1953 triggered a comprehensive structural coastal defence program.

The RIVM study of 2004 paved the way for studies focusing on flood impact (Warner et al. 2008). In 2006 two Delft-based authorities on flood risk management, Prof. Vrijling and Prof. Stive, had sounded the alarm that the Netherlands were not safe enough. By that time climate fears were reaching their peak. A second Delta Commission (state advisory commission) was mandated to consider the next two centuries and see if the Dutch could keep themselves safe even in extreme scenarios.

Meanwhile the risk mapping exercise concerning the actual strength of dikes, as described earlier, revealed ever more problems, which started to become a political risk. Although the uncertainty in the design of dikes under the original Delta Plan had been assessed at 10\%, and compensated by generous freeboard (waakoverhoogte), progressive insight suggested that uncertainty may outpace certainty. Remedying this extent of uncertainty was becoming a costly liability. This insight incited the current Water Minister to push for bringing back the focus to the original vision of the first Delta Commission, established after the 1953 flood: a risk-based $(\mathrm{R}=\mathrm{p} * \mathrm{i})$ approach that incorporates both flood protection in light of increased probability of flood (p) but limits the impact (i) of a possible flood: the hugely increased number of elements at risk behind the dikes (people, livestock, and assets) would generate a dramatically multiplied impact in case of a flood.

Europe meanwhile suffered over more than 100 major damaging floods between 1998 and 2006. This caused the European Commission to propose a Floods Directive (Directive 2007/60/ EC). The aim of the directive is "to reduce and manage the risks that floods pose to human health, the environment, cultural heritage and economic activity." With this directive the urgency to promote more resilient modalities of flood risk management in the Netherlands increased considerably.

In 2008, the second Delta Commission presented its report on the challenges of climate change on water management in the Netherlands. Although the report does not specifically refer to multilayer safety, the Delta Commission looks beyond dikes, discussing river widening as a preventative technology, as well as measures for mitigation (zoning in spatial planning and building regulations) and preparation (Delta Commission 2008) without actually advocating them. The Commission's a priori starting point after all was that the Dutch should be able to live and build anywhere they like.

However, the door was ajar, and by 2009 the concept of MLS had become a core policy concept, introduced as a core building block of the Dutch National Water Plan (NWP), with enthusiastic backing from the responsible Minister. Instead of giving a clear definition and pathway forward to implementation, the NWP explicitly introduced a learning approach. The plan argues that a tailor-made approach is needed and therefore the process of further defining and designing the concept of MLS will be done together with the regional and local authorities by means of pilot studies (Ministry Of Public Transport and Water 2009).

After the publication of the NWP and based on the recommendations of the report of the second Delta Commission, a Delta act was created. This act had three key elements: the annual presentation of a Delta Programme, a new institute, the "Delta Commissioner," and finally the instatement of the Deltafund. In 2010 the Delta Commissioner, a special national government officer charged with overseeing the Delta Programme, was instated and he started the Delta Programme in 2011. The Delta Programme's main goals are the following:

1. New flood protection standards will be set: these will not only be linked to the probability of flooding, but also to the 
impact of a flood (risk-based approach). The scope of the impact is the decisive factor in setting the standard;

2. The availability of freshwater for agriculture, industry, and nature will become more predictable;

3. Spatial planning will become more climate-proof and waterrobust.

The Delta Programme also placed the issue of MLS on its agenda as a cross-sectoral issue between flood protection and spatial planning and undertook a sequence of activities:

- 2011: The publication of a more explorative approach of the first series of pilot locations in the Netherlands that are considered suitable for MLS. The main conclusion of this report is that MLS is approached enthusiastically and energetically and that there is a strong desire of the involved local and regional authorities to explore the opportunities of MLS further.

- 2012: To calculate the effectiveness of possible MLS measures, a toolkit was developed funded by the knowledge organization of the regional water authorities and the Delta Programme.

- 2013: Design workshops on MLS initiated by the Delta Programme were organized to create building blocks for the Delta Programme on MLS and also give regional and local authorities tailor-made designs for MLS. During this time, especially in 2011-2012 the concept of MLS was strongly resisted by the traditional civil-engineering minded proponents of dikes. A heated exchange in the widely read online professional news site Waterforum (2012) in 2012 bears testimony to this standoff (see also Jongejan et al. 2012).

- 2014: Three regional pilot projects were started to explore the scope for downscaling flood protection by means of dikes (and to lower the standards for flood protection) in combination with additional measures pertaining to the second and third layer.

Late 2014, the main results of the Delta Programme were laid down in so-called Delta Decisions, which were ratified by the national government and the Parliament. In two of them elements of multilayer safety were included. One Delta decision was devoted to the issue of land-use adaptation or water-robust planning (to arrive at more risk-neutral area development, on a voluntary basis). The Delta Decision taken on flood-risk safety incorporated the possibility of "smart combinations." The latter is aimed to provide the opportunity for exceptional situations in which dike enforcement can be replaced by a combination of measures in the first, second, and third layer: partial dike enforcement, measures in the spatial domain (compartmenting, water proof development), and evacuation or risk reduction. Three pilot cases were selected to explore the possibilities.

The Delta Programme adopted the philosophy of Adaptive Delta Management based upon the idea of Dynamic Adaptive Policy Pathways (Jeuken et al. 2015). For all regions the Delta Decisions were translated in a "regionally preferred implementation strategy." The regional strategies were translated in adaptation pathways, by investigating critical tipping-points and thresholds.
In this pathway analysis the strategy of flood-proof urban areas is presented as a building block, at least for the long term (as in the case of the main rivers) or for both the short and the long term (as in the case of the highly urbanized Rotterdam region). However, the fact that it is included in these pathways does not imply that it is part of formal policies.

The new flood risk standards will have to be met by 2050 . This gives the water boards many opportunities to select the most urgent trajectories (where the gap between the actual performance of the dike and the norm is very large) first and to develop alternative strategies for less urgent trajectories. However, the current focus of the Water Management Boards is mainly on the most urgent trajectories: they simply do not have the resources to consider averting further dike improvements with help of landuse measures.

\section{Policy learning: results}

First of all, we observe a growing recognition that, even in the Netherlands, complete protection against floods is impossible. There is a growing awareness among policy makers and politicians that we cannot avoid considering residual risk. This is strongly expressed by the current Minister of Public Works, Schultz van Haegen, who emphasizes the importance of being prepared for a serious flood event. It is also laid down in various policy documents, such as the recently published National Water Plan 2 (2015). Moreover, from the late 1990s on there has been a growing recognition that it is important to link flood risk management to land-use planning, to consider the consequences of building deep polders and to mitigate the consequences of land use for flood management.

Finally, there is a growing recognition, although not universally within the flood risk community, that customary flood protection measures, focused upon strengthening the first layer, no longer suffice as a blanket solution, especially should anticipated climate change consequences such as increased flood frequency worsen, and that measures taken in the second and third layers can function as a valuable addition. The support for risk reducing measures is also reflected in statements by the Union of Water Boards (2012) and by various respondents interviewed for this research.

We can conclude that not only external causes (climate change, economic growth) but mainly internal causes trigger a process of policy learning (Table 3). New insights, not only on the increasing difficulties of a flood protection strategy but also on residual risk, and a changing network context, triggered by the Delta Programme, which introduced new approaches and invited other actors to coproduce the so-called Delta Decisions, were important for the ultimate formulation of the Delta Decisions on Spatial Adaptation and on Flood Safety.

\section{REGIME ADJUSTMENTS IN DUTCH FLOOD MANAGEMENT}

During the development of the Delta Programme some important choices were made. First, new flood risk standards (to be implemented in 2017) are exclusively translated into standards for determining the required strength and height of the dikes. Although mortality rates were incorporated into these standards, no legally binding and enforceable standards have been introduced for the second and third layer. While some pilot studies 
Table 3. Triggers for policy learning in Dutch flood management.

\section{External triggers \\ Changes in socioeconomic conditions}

Changes in public opinion

Changes in systemic governing coalition

Internal drivers

New insights from science

Existing strategies fail

New actors
Socioeconomic development increases impact of potential flood, inciting higher protection standards (acknowledged by second Delta Commission).

Reinforced by progressive scientific insights, bringing dikes up to standard becomes almost unaffordable in the long term.

No significant changes. In the Netherlands people think they are protected well (Baan et al. 2008, OECD 2014).

Rapprochement of land and water management:

Since near-floods of 1993 and 1995 water boards have become more involved in spatial planning and development issues.

Interauthority agreement about Water Assessment (2001): flood capacity reservation in new spatial developments.

Creation of the Delta act: Delta Programme, Delta Commissioner and Delta Fund. explored lowering the protection standards for the first layer in favor of additional investments in the second and third layer, none of the ideas generated was translated into a change of the formal standards for the dikes.

Second, the allocation of responsibilities and financial means has not been altered. For example, the distribution of resources available for flood risk management is still coordinated by a wellendowed national program on flood protection (HWBP). This program does not allow its money to be made available for investments pertaining to the second or third layer.

That also means that the water authorities continue to be able to realize high levels of flood safety in "splendid isolation." The institutional machinery to realize dike reinforcement is powerful and its funding is safeguarded for the next 15 years. The incentives to do anything additionally are thus weak if not absent.

Third, the success of MLS is made dependent solely upon the voluntary collaboration of public authorities involved. That also means there is no incentive in case the various governments prove unwilling to devote sufficient attention and resources to making plans and formulating strategies for water-robust planning.

Fourth, the above is also clearly visible in the formulation of the Delta Decision on spatial adaptation. This decision consists of intentions and affirmations of current practice, such as the importance of using the legally binding water assessment early in a spatial planning process. Future ambitions have a very long time line, 2050, while arrangements to monitor and evaluate progress in implementing the decision are only covered until 2017.
Ultimately, the extent of actual institutional adjustments thus nearly come to zero. The current system of flood risk management remains focused upon flood protection, only reinforced by the higher protection standards to be implemented in 2017. The concept of MLS is kept at a distance from the flood risk domain and is left for the other governments in the planning domain (local, provincial, and national) to tackle. With the help of soft instruments to promote land-use adaptation (sharing best practices, knowledge program, communication) the concept of water-robust planning will be elaborated on in the next coming years. The three regional pilot projects show that while regional actors were very successful in developing creative strategies to implement MLS strategies, these are mainly pursued "in addition to" structural flood protection. The pilot projects, however, still face (institutional) barriers to the implementation of these measures. These barriers, for example, concern administrative restrictions about using budgets of flood prevention for spatial measures and vice versa, a lack of suitable instruments to lend measures related to the second and third layer a formal status, and difficulties to convince the various agencies involved about the feasibility and value added of these innovative measures (Van Buuren et al. 2015b).

The mode of institutional change can be mainly depicted as "reproduction by adaptation" (Streeck and Thelen 2005). The current institutional arrangements remain intact; the current distributions of roles and responsibilities and formal rules do not change. New concepts are (discursively) incorporated, but also externalized: they are put on the agenda of local authorities and regional safety authorities; the water authorities can focus upon 
Table 4. Mechanisms of path dependency.

\begin{tabular}{|c|c|c|}
\hline Source of path dependency & Mechanism of path dependency & Impact on regime change \\
\hline The collective nature of politics & $\begin{array}{l}\text { Citizens expect that government takes care of } \\
\text { flood protection and are nearly not aware of flood } \\
\text { risks. }\end{array}$ & $\begin{array}{l}\text { Implementing more resilient approaches } \\
\text { necessitates a change in the mindset of } \\
\text { citizens, which is very difficult. }\end{array}$ \\
\hline $\begin{array}{l}\text { The possibilities of using political power to } \\
\text { enhance power asymmetries }\end{array}$ & $\begin{array}{l}\text { The existing distribution of resources is skewed } \\
\text { toward prevention. Therefore new elements have a } \\
\text { backlog. }\end{array}$ & $\begin{array}{l}\text { The concept of multilayered safety is defined } \\
\text { as an add-on to prevention, without } \\
\text { reallocating budgets and competencies. }\end{array}$ \\
\hline The intrinsic complexity of politics & $\begin{array}{l}\text { Standards for the second and third layer are } \\
\text { framed as too complex to be introduced at the } \\
\text { same time. }\end{array}$ & $\begin{array}{l}\text { No standards are initiated for the second and } \\
\text { third layer, making water robust planning a } \\
\text { voluntary bonus to prevention. }\end{array}$ \\
\hline The intrinsic opacity of politics & $\begin{array}{l}\text { Attention is monopolized by the debate on new } \\
\text { flood standards and their translation in new } \\
\text { standards for prevention. }\end{array}$ & $\begin{array}{l}\text { Almost no attention remains for developing } \\
\text { new ways of thinking (except from some pilot } \\
\text { projects). }\end{array}$ \\
\hline
\end{tabular}

flood defence, especially because they need to meet higher protection standards. Because policy ambitions with regard to multilayer safety remains voluntary and nonbinding, it is questionable whether the first layer will lose some of its dominant position. Policy incentives to pilot and upscale complementary or substituting nonstructural measures are badly needed to promote more resilient flood risk management in the Netherlands.

In terms of Streeck and Thelen (2005) the regime survived through adaptation. Discursively, paradigm shifts were pronounced espoused adapting to the spirit of the times, but at the core, things fundamentally remained the same (Scrase and Sheate 2005; cf. Wiering and Arts 2006 for the UK). Giving alternative ideas the position of sympathetic but noncrucial supplements means the dominant idea that the Netherlands will need to do as much as possible to prevent rather than accommodate flooding is safeguarded. This illustrates what Hinnfors (1999) calls stability through change and the persuasiveness of political ideas. The various sources of negative feedback (in terms of attractive alternative policy options and shortcomings of the current paradigm) do not equal the strength of the positive feedbacks from the current policy regime (Weaver 2010).

\section{MECHANISMS OF PATH DEPENDENCY AND POLICY STICKINESS}

Turning now to the sources for path dependency as formulated by Pierson (2000), four of them are of particular relevance to understanding how path dependency impacts upon the process of learning in the Dutch flood management domain and why we see only marginal regime change. Table 4 summarizes these mechanisms.

\section{The collective nature of politics}

Flood risk management is strongly embedded in the Dutch legal system. As described in the introduction, the historical development in the Netherlands gave the country a strong focus on flood risk management. Since 1953 Dutch society has slowly stopped thinking about the possibility of a flood ever occurring, because it is believed to "have been taken care of" (Saeijs et al. 2004). Citizens have also come to expect that they are safe. Their flood risk awareness is dramatically low (OECD 2014). It is therefore difficult to convince them of the necessity of risk reduction and the value added of doing so. These embedded expectations of protection and safety reinforce the current path of prevention.

\section{The scope for using political power to enhance power} asymmetries

The use of political power to enhance power asymmetries can be clearly seen when it comes to the role of the core players within the flood domain to forestall institutional adjustments and adjustments of the financial rules of the game. Until now all money available for flood risk management has been exclusively devoted to flood protection. Especially the Water Management Boards keep stressing that this budget is already too small as it is, and thus that it is impossible to devote a part of it to risk reduction. The Flood Defences Committee of the National Union of Water Boards organized a powerful lobby to the national Department of Infrastructure and the Parliament, and succeeded in keeping the rules for financing measures from the so-called Delta Fund quite restrictive and focused on protection (notes Flood Defences Committee, 11 October 2011, 13 September 2013). The strong position of the Water Boards in several formal consultative forums enabled them to make their point effectively.

These power asymmetries are further intensified by the position of flood risk experts and their surrounding epistemic community. As noted, there is quite a strong position from experts in the Dutch flood domain, who are closely involved in adjustments of flood risk policy proposals and the legal design and evaluation instrument (WTI). A consequence is that new policy ideas are translated into questions that fit within the models and approaches of the old epistemic tradition focused upon flood protection. Policy alternatives are evaluated with help of criteria derived from the old paradigm, which makes it difficult to get a really fair comparison. As Rooijendijk (2009) describes, the leading Dutch dike experts consider continuing along the historic path of dike reinforcement to be the safest, cheapest, and most feasible vision on flood risk management in the Netherlands, if perhaps by unconventional means.

In the course of the Delta Programme it became clear that legal adjustments, such as creating standards for layers 2 and 3 , or a redistribution of responsibilities, were perceived as too difficult to realize. All attention was given to the design of the new flood risk standards (to be implemented in 2017). The proposals for MLS has to fit into the existing institutional conditions (Van 
Buuren and Ellen 2013). Actors involved feared the complexity and transaction costs of legal adjustments, such as standards for layers 2 and 3 or redistribution of responsibilities and funds, and thus developed proposals that do not impact upon the existing distribution of responsibilities in the hope that these proposals get enough support.

\section{The intrinsic complexity of Dutch flood politics}

The majority of public-sector stakeholders (local, regional, national authorities) appear to consider the Delta Programme as quite successful because it managed to propose new flood risk standards. This was always going to be a difficult job because of the many technical details and political controversies surrounding the new standards. These controversies include risk calculations, assumptions with regard to evacuation fractions, the socioeconomic impact of a flood, the criteria to locally opt for higher standards because of the presence of specific amenities (like a nuclear plant), and the way in which the flood risk standards are to be translated into technical standards for the flood defence infrastructure. Especially, representatives from the water domain have suggested that the Delta Programme would need to develop quantitative protection standards for the second and third layers in MLS. This was not supported by local and regional authorities because they considered implementing and enforcing mandatory standards for water-robust planning too complex from an administrative perspective. Most stakeholders preferred to spend their energy on developing new flood risk standards and not to make that challenge even more complex.

\section{The intrinsic opacity of politics}

Not only is Dutch flood management a heavily techno-centric policy domain, it is also very strongly legalized. Even the guidelines on dike design and maintenance are legally embedded and the legally enshrined standards are difficult to change. The actual application of the standards, the assumptions underlying the legal guidelines, and the research being conducted to map the risks of the strengths of dikes, are very difficult to grasp by outsiders, and will be even more opaque under the new standards. The various water authorities are very busy translating the new flood risk standards into their procedures and routines, which is perceived as a really tough job. Here we can also see a propensity for complexity reduction: for these authorities the substantial complexity of implementing the new standards is very high. They therefore try to translate the new standards into their existing procedures as much as possible. Developing new ways of doing within an institutional vacuum is difficult to address in organizations busy with many challenges and with shrinking budgets.

\section{CONCLUSION: MECHANISMS OF PATH-DEPENDENCY}

There are serious indications that the Dutch focus on structural flood protection is broadened to include aspects of water-robust planning and risk reduction. This evolution contributes to the resilience of flood risk management and reduces the exclusive reliance on hard infrastructure. This broadening is especially triggered by policy-internal factors, which are fuelled by the Delta Programme. External triggers such as climate change and economic dynamics created a fruitful context for the salience of risk reduction to grow, but did not present a "shock" to the system that might have triggered a regime shift. The relative success of flood protection has made the Dutch fall into the trap of evolving systems, which "are easily locked into their own success and selection criteria, which were built in the past and constrain the future through selective perception and path dependency." (Rammel et al. 2007:17). As a result, the impact of this cautious learning process in terms of institutional change is still minor. The new insights would presuppose altering existing rules and arrangements, but here, policy learning goes without institutional change. This also means that the resilience of Dutch flood risk management is only slightly increased, mainly because of the voluntary efforts made by regional and local authorities.

When we reflect upon whether the mechanisms of path dependency actually work, we can see three patterns. First, it proved difficult to mobilize sufficient momentum and resources at the right time for the issue of multilayer safety and reduction of the consequences of flooding. The Delta Programme created momentum for more radical policy change but this momentum could only partly be seized because all energies were devoted to setting and implementing the new (2017) flood risk standards in regional hotspots ${ }^{[2]}$ and charting the strategies for implementing these standards.

Furthermore, an important pattern involves giving preference to existing ways of knowing or epistemic traditions and translating research questions about new policy ideas into the models and approaches of the old paradigm. Effectuating policy learning can be seriously hampered when a dominant epistemic community is in the position to stick to tried and tested strategies and dominant insights, currently reinforced through the nature of the policy changes and are strongly embedded in the national psyche.

Finally, there is a pattern of framing the flood issue such that existing power asymmetries are reinforced rather than broken down. Exponents of the traditional approach exaggerate the complexity of multilayer safety, while banking on the general public opinion that the government is responsible for preventing floods. They also emphasize the disastrous consequences when the importance of flood prevention becomes underestimated as a possible consequence of multilayer safety (see, for example, Expertise Network for Flood Protection 2012).

There is no obvious need to make things technical and complicated, given that multilevel safety is not a novelty in the flood management university; rather, the Netherlands can be said to have belatedly adopted what a flock of flood-prone countries have adopted: more or less workable flood risk policies that combine structural measures, land-use planning, and crisis management. The currently adopted "softly-softly" approach of piloting MLS approaches promotes new knowledge and learning, but avoids the more painful debate about reallocating responsibilities or reformulating normative flood risk management principles (Keessen et al. 2013). Nevertheless, the pilot projects keep the issue on the agenda and enables proponents for a paradigm shift to accumulate the burden of proof for a more fundamental reconsideration of Dutch flood policies.

[1] Any mention of and provisioning for uncertainty and contingency has long been a taboo in the water department (interview with Silva 2005). To accept resilience is to accept uncertainty, a limit to technical control, which water managers have long perceived as almost existentially threatening. Instead, 
the term "robustness" was used, as this article does. Some consider the term to be equivalent to resilience, whereas others associate it with insensitivity to uncertainties (Mens et al. 2011).

[2] The Delta Programme has identified a number of regions ("hotspots") in which flood or drought risk is particularly worrying, and set in motion regional decision making to concretize adaptation plans at this regional level.

Responses to this article can be read online at: http://www.ecologyandsociety.org/issues/responses. $\mathrm{php} / 8765$

\section{LITERATURE CITED}

Aerts, J. C. J. H., W. J. W. Botzen, K. Emanuel, N. Lin, H. de Moel, and E. O. Michel-Kerjan. 2014. Evaluating flood resilience strategies for coastal megacities. Science 344(6183):473-475. http://dx.doi.org/10.1126/science.1248222

Arthur, W. B. 1994. Increasing returns and path dependence in the economy. University of Michigan Press, Ann Arbor, Michigan, USA. http://dx.doi.org/10.3998/mpub.10029

Baan, M. E., J. M. Gutteling, and T. Terpstra. 2008. Risicoperceptie en risicocommunicatie bij overstromingen. University of Twente, Enschede, The Netherlands.

Becker, G., D. Huitema, and J. C. J. H. Aerts. 2015. Prescriptions for adaptive comanagement: the case of flood management in the German Rhine basin. Ecology and Society 20(3):1. http://dx.doi. org/10.5751/ES-07562-200301

Brand, F. S., and K. Jax. 2007. Focusing the meaning(s) of resilience: resilience as a descriptive concept and a boundary object. Ecology and Society 12(1):23. [online] URL: http://www. ecologyandsociety.org/vol12/iss1/art23/

De Bruijn, K. M. 2004. Resilience and flood risk management. Water Policy 6:53-66.

Delta Commission. 2008. Working together with water. A living land builds for its future. Delta Commission, The Hague, The Netherlands.

Ellen, G. J., and M. W. van Buuren. 2014. De governance van slimme combinaties. Spelregels voor samenwerking rond meerlaagse vormen van waterveiligheid. External report no. 1208559-000. Deltares, Utrecht, The Netherlands.

Ellen, G. J., R. van Duinen, and M. W. van Buuren. 2013. Beelden van meerlaagsveiligheid, enquete resultaten en analyse. External report no. 1208559-000-VEB-0010. Deltares, Utrecht, The Netherlands.

Expertise Network for Flood Protection (ENW). 2012. Meerlaagsveiligheid nuchter bekeken. ENW, The Hague, The Netherlands.

Folke, C., T. Hahn, P. Olsson, and J. Norberg. 2005. Adaptive governance of social-ecological systems. Annual Review of Environmental Resources 30:441-473. http://dx.doi.org/10.1146/ annurev.energy.30.050504.144511
Geels, F. W. 2004. From sectoral systems of innovation to sociotechnical systems: insights about dynamics and change from sociology and institutional theory. Research Policy 33 (6-7):897-920. http://dx.doi.org/10.1016/j.respol.2004.01.015

Gerrits, L., and P. Marks. 2008. Complex bounded rationality in dyke construction: path-dependency, lock-in in the emergence of the geometry of the Zeeland delta. Land Use Policy 25(3):330-337. http://dx.doi.org/10.1016/j.landusepol.2007.09.001

Hegger, D. L. T., P. P. J. Driessen, M. H. N. Bakker, editors. 2016. $A$ view on more resilient flood risk governance: key conclusions of the STAR-FLOOD project. STAR-FLOOD consortium, Utrecht, The Netherlands. ISBN: 978-94-91933-13-4.

Hinnfors, J. 1999. Stability through change: the pervasiveness of political ideas. Journal of Public Policy 19(03):293-312. http://dx. doi.org/10.1017/s0143814x99000719

Howlett, M., and B. Cashore. 2009. The dependent variable problem in the study of policy change: understanding policy change as a methodological problem. Journal of Comparative Policy Analysis: Research and Practice 11(1):33-46. http://dx.doi. org/10.1080/13876980802648144

Immink, I. 2007. Voorbij de risiconorm, nieuwe relatie tussen ruimte, water en risico. Wageningen Universiteit, Wageningen, The Netherlands.

Ingram, H., and L. Fraser. 2006. Path dependency and adroit innovation: the case of California water. Pages 78-109 in R. Repetto, editor. Punctuated equilibrium and the dynamics of US environmental policy. Yale University Press, New Haven, Connecticut, USA.

Jeuken, A., M. Haasnoot, T. Reeder, and P. Ward. 2015. Lessons learnt from adaptation planning in four deltas and coastal cities. Journal of Water and Climate Change 6(4):711-728. http://dx.doi. org/10.2166/wcc.2014.141

Jongejan, R. B., S. N. Jonkman, and J. K. Vrijling. 2012. The safety chain: a delusive concept. Safety Science 50(5):1299-1303. http://dx.doi.org/10.1016/j.ssci.2011.12.007

Kay, A. 2005. A critique of the use of path dependency in policy studies. Public Administration 83(3):553-571. http://dx.doi. org/10.1111/j.0033-3298.2005.00462.x

Keessen, A. M., J. M. Hamer, H. F. M. W. Van Rijswick, and M. Wiering. 2013. The concept of resilience from a normative perspective: examples from Dutch adaptation strategies. Ecology and Society 18(2):45. http://dx.doi.org/10.5751/ES-05526-180245

Klijn, F., M. van Buuren, and S. A. M. van Rooij. 2004. Floodrisk management strategies for an uncertain future: living with Rhine river floods in the Netherlands? AMBIO 33(3):141-147. http://dx.doi.org/10.1579/0044-7447-33.3.141

Mens, M. J. P., F. Klijn, K. M. De Bruijn, and E. van Beek. 2011. The meaning of system robustness for flood risk management. Environmental Science \& Policy 14(8):1121-1131. http://dx.doi. org/10.1016/j.envsci.2011.08.003

Menz, F. C., and S. Vachon. 2006. The effectiveness of different policy regimes for promoting wind power. Experiences from the states. Energy Policy 34(14):1786-1796. http://dx.doi.org/10.1016/ j.enpol.2004.12.018 
Ministry of Public Transport and Water. 2009. Nationaal Waterplan. Ministry of Public Transport and Water, The Hague, The Netherlands.

Mostert, E. 2006. Integrated water resources management in the Netherlands: how concepts function. Journal of Contemporary Water Research \& Education 135(1):19-27. http://dx.doi. org/10.1111/j.1936-704x.2006.mp135001003.x

Organisation for Economic Co-operation and Development (OECD). 2014. Water governance in the Netherlands: fit for the future? OECD Studies on Water, OECD Publishing, Paris, France. http://dx.doi.org/10.1787/9789264102637-en

Pahl-Wostl, C., G. Becker, C. Knieper, and J. Sendzimir. 2013. How multilevel societal learning processes facilitate transformative change: a comparative case study analysis on flood management. Ecology and Society 18(4):58. http://dx.doi.org/10.5751/ es-05779-180458

Peters, B. G., J. Pierre, and D. S. King. 2005. The politics of path dependency: political conflict in historical institutionalism. Journal of Politics 67(4):1275-1300. http://dx.doi.org/10.1111/ j.1468-2508.2005.00360.x

Pierson, P. 2000. Increasing returns, path dependence, and the study of politics. American Political Science Review 94 (2):251-267. http://dx.doi.org/10.2307/2586011

Pols, L., P. Kronberger, N. Pieterse, and J. Tennekes. 2007. Overstromingsrisico als ruimtelijke opgave. NAi Uitgevers, Rotterdam, Ruimtelijk Planbureau, Den Haag, The Netherlands.

Rammel, C., S. Stagl, and H. Wilfing. 2007. Managing complex adaptive systems - a co-evolutionary perspective on natural resource management. Ecological Economics 63(1):9-21. http:// dx.doi.org/10.1016/j.ecolecon.2006.12.014

Reed, M., and D. L. Harvey. 1992. The new science and the old: complexity and realism in the social sciences. Journal for the Theory of Social Behaviour 22(4):353-380. http://dx.doi. org/10.1111/j.1468-5914.1992.tb00224.x

Rooijendijk, C. 2009. Waterwolven. Uitgeverij Atlas, Amsterdam, The Netherlands.

Sabatier, P. A. 1993. Policy change over a decade or more. Westview, Boulder, Colorado, USA.

Saeijs, G. E. M., M. H. P. Otten, M. J. van Duin, and U. Rosenthal. 2004. Essay de perceptie van veiligheid tegen overstromingen door politici en bestuurders. COT Instituut voor Veiligheids- en Crisismanagement, Rotterdam, The Netherlands.

Scrase, J. I., and W. R. Sheate. 2005. Re-framing flood control in England and Wales. Environmental Values 14(1):113-137. http:// dx.doi.org/10.3197/0963271053306131

Sjöstedt, M. 2015. Resilience revisited: taking institutional theory seriously. Ecology and Society 20(4):23. http://dx.doi.org/10.5751/ $\underline{\text { es-08034-200423 }}$

Stone-Jovicich, S. 2015. Probing the interfaces between the social sciences and social-ecological resilience: insights from integrative and hybrid perspectives in the social sciences. Ecology and Society 20(2):25. http://dx.doi.org/10.5751/ES-07347-200225
Streeck, W., and K. Thelen. 2005. Beyond continuity: explorations in the dynamics of advanced political economies. Oxford University Press, Oxford, UK.

Ten Brinke, W., and B. Bannink. 2004. Risico's in bedijkte termen: een thematische evaluatie van het Nederlandse veiligheidsbeleid tegen overstromen. RIVM, Bilthoven, The Nethelands.

Van Buuren, A., K. Potter, J. Warner, and T. Fischer. 2015a. Making space for institutional change? A comparative case study on regime stability and change in river flood management in the Netherlands and England. International Journal of Water Governance 4(3):81-100.

van Buuren, M. W., and G. J. Ellen. 2013. Multilevel governance voor meerlaagsveiligheid. Met maatwerk meters maken. Erasmus University Rotterdam, Rotterdam, The Netherlands.

van Buuren, M. W., G. J. Ellen, J. van Popering-Verkerk, and C. W. G. J. van Leeuwen. 2015b. Die het water deert die het water keert: Overstromingsrisicobeheer als maatschappelijke gebiedsopgave. Opbrengsten en lessen uit de pilots meerlaagsveiligheid, Erasmus University Rotterdam, Rotterdam, The Netherlands.

van den Brink, M. A., and S. Meijerink. 2006. Implementing policy innovations: resource dependence, struggle for discursive hegemony and institutional inertia in the Dutch river policy domain. Radboud University Nijmegen, The Netherlands. [online] URL: http://repository.ubn.ru.nl/bitstream/ handle/2066/45540/45540.pdf

van der Brugge, R. 2009. Transition dynamics in social-ecological systems: the case of Dutch water management. Dutch Research Institute for Transitions (DRIFT), Rotterdam, The Netherlands.

Van der Horst, S. 2013. Tussen fragmentatie en integratie, complexiteit en de governance van meerlaagsveiligheid in Marken. Thesis. Erasmus University Rotterdam, Rotterdam, The Netherlands.

van der Most, H. 2010. Kijk op waterveiligheid. Eburon, Delft, The Netherlands.

van Hemert, M. 1999. Ruimte voor de ingenieur. Rivierbeheer in Nederland eind jaren negentig. $K \& M$, Tijdschrift voor Empirische Filosofie 361-387.

van Zuijlen, N. 2012. Bevordering van samenhang tussen de lagen van meerlaagsveiligheid: een studie naar beleidsarrangementen en institutioneel handelen. Thesis. Governance en management of complexe systemen. Erasmus University Rotterdam, Rotterdam, The Netherlands.

Verkerk, J., and A. van Buuren. 2013. Integrated water resources management in the Netherlands. Historical trends and current practices in the governance of integration. International Journal of Water Governance 1(3-4):427-452. http://dx.doi.org/10.7564/13IJWG6

Vis, M., F. Klijn, K. M. de Bruijn, and M. van Buuren. 2003. Resilience strategies for flood risk management in the Netherlands. International Journal of River Basin Management 1 (1):33-40. http://dx.doi.org/10.1080/15715124.2003.9635190

Warner, J., S. Meijerink, and B. Needham. 2008. Sturen in de ruimte? Een evaluatie van beleidsinstrumenten voor gevolgenbeperking 
bij overstromingen. A Report commissioned by the Ministry of Public Works. Wageningen University, Social Sciences Group, Wageningen, The Netherlands.

Warner, J., A. van Buuren, and J. Edelenbos. 2013. Making space for the river. IWA London, UK.

Waterforum. 2012. TU Delft-onderzoeker Rijcken plaatst vraagtekens bij meerlaagsveiligheid. Waterforum, 27 June.

Weaver, K. 2010. Paths and forks or chutes and ladders: negative feedbacks and policy regime change. Journal of Public Policy 30 (2):137-162. http://dx.doi.org/10.1017/s0143814x10000061

Wesselink, A., J. Warner, M. Abu Syed, F. Chand, D. Duc Trane, H. Huq, F. Huthoff, N. Le Thuyh, N. Pinter, M. van Staveren, P. Wester, and A. Zegwaard. 2015. Trends in flood risk management in deltas around the world: Are we going 'soft'? International Journal of Water Governance 4(4):25-46.

Wiering, M., and B. J. M. Arts. 2006. Discursive shifts in Dutch river management: 'deep' institutional change or adaptation strategy? Hydrobiologia 565(1):327-338. http://dx.doi.org/10.1007/ $\underline{\text { s10750-005-5923-2 }}$

Wildavsky, A. B. 1985. Trial without error: anticipation vs resilience as strategies for risk reduction. Centre for Independent Studies, Sydney, Australia.

Wilsford, D. 1994. Path dependency, or why history makes it difficult but not impossible to reform health care system in a big way. Journal of Public Policy 14(3):251-283. http://dx.doi. org/10.1017/s0143814x00007285

Wison, C. A. 2000. Policy regimes and policy change. Journal of Public Policy 20(3):247-274. http://dx.doi.org/10.1017/s0143814x00000842 